\title{
Perempuan dan Kesejahteraan Rumah Tangga Sektor Informal di Indonesia
}

\author{
Vitriyani Tri Purwaningsih ${ }^{\mathrm{a}, *}$ \\ a Universitas Gadjah Mada, Yogyakarta
}

\begin{abstract}
Households led by women exhibit higher tendency to work in the informal sector which has low income. This study aims to look at the welfare differences between informal and formal workers among households led by women. The study uses secondary data from the 2014 Indonesia Family Life Survey (IFLS), and employs the Two-Stage Least Squares (2SLS) analysis method in estimating the welfare differences. The findings of this study indicate that households headed by women who work in the informal sector have lower welfare than formal sector households. Women who are older, own agricultural land and have savings are able to increase monthly per capita expenditure. This study concludes that there are gaps between the two sectors but asset ownership can increase welfare among female households.
\end{abstract}

Keywords: women; welfare; informal; households; IFLS

\begin{abstract}
Abstrak
Rumah tangga yang dipimpin oleh perempuan cenderung lebih banyak berkerja pada sektor informal yang memiliki pendapatan rendah. Penelitian ini bertujuan untuk melihat kesejahteraan antara pekerja informal dan formal di antara rumah tangga yang dipimpin oleh seorang perempuan. Data yang digunakan merupakan data sekunder yang berasal dari Indonesia Family Life Survey (IFLS) 2014, dengan metode analisis Two Stage Least Square (2SLS) menggunakan pendekatan instrumental variable. Temuan dari penelitian ini menyatakan bahwa rumah tangga yang dikepalai oleh perempuan yang bekerja di sektor informal memiliki kesejahteraan yang lebih rendah dibandingkan dengan rumah tangga sektor formal. Usia kepala rumah tangga perempuan yang lebih dewasa, memiliki lahan pertanian dan tabungan mampu meningkatkan pengeluaran per kapita bulanan. Penelitian ini menyimpulkan bahwa adanya kesenjangan antar sektor namun kepemilikan aset dapat meningkatkan kesejahteraan di antara rumah tangga perempuan.
\end{abstract}

Kata Kunci: perempuan; kesejahteraan; informal; rumah tangga; IFLS Kode Klasifikasi JEL: D60; I31; J71; O17

*Alamat Korespondensi Penulis: Fakultas Ekonomika dan Bisnis, Universitas Gadjah Mada, Jl. Sosio Humaniora No.1, Bulaksumur, Caturtunggal, Sleman, 55281. E-mail: vitriyanitp@gmail.com. 


\section{Pendahuluan}

Di dalam ketenagakerjaan, Indonesia tercatat memiliki kenaikan jumlah penduduk yang bekerja. Laporan dari Badan Pusat Statistik/BPS (2018) menyebutkan bahwa terdapat tambahan sebanyak 2,99 juta penduduk yang bekerja. Pada Agustus 2018, terdapat 53,52 juta penduduk (43,16\%) bekerja pada sektor formal dan 70,49 juta $(56,84 \%)$ bekerja pada sektor informal. Sektor informal merupakan jenis pekerjaan yang lebih banyak dipilih oleh masyarakat Indonesia karena sektor tersebut lebih fleksibel dan bahkan tidak membutuhkan pendidikan dan keterampilan khusus. Selain itu, pekerjaan sektor informal dapat dilakukan oleh siapapun baik laki-laki maupun perempuan. Meskipun demikian, perempuan cenderung berpartisipasi pada pekerjaan sektor informal (Narayan, 2011; SOFA Team \& Doss, 2011) dan non-pertanian (Canagarajah et al., 2001; Rijkers \& Costa, 2012).

Gallaway \& Bernasek (2002) menemukan pendidikan dan pengasuhan anak merupakan faktor yang berperan dalam keputusan perempuan bekerja. Mayoritas kegiatan perempuan akan bergerak di sektor perdagangan (Rijkers \& Costa, 2012). Di negara-negara kawasan Afrika Sub-Sahara, perusahaan yang dipimpin oleh seorang perempuan dan berlokasi di pedesaan akan memiliki tingkat produktivitas tenaga kerja yang lebih rendah dibandingkan perusahaan di perkotaan (Nagler \& Naudé, 2017). Hal tersebut dapat dikarenakan lokasi dan akses yang terbatas, Rijkers \& Costa (2012) juga menambahkan bahwa perusahaan yang dipimpin oleh perempuan cenderung berukuran lebih kecil dan kurang produktif seperti yang terjadi di Bangladesh, Ethiopia, dan Sri Lanka, namun tidak berlaku di Indonesia. Selain dari segi ukurannya yang kecil, perusahaan perempuan biasanya merupakan usaha rumah tangga dan hanya mempekerjakan satu orang pekerja sehingga rata-rata penjualan di perusahaannya lebih rendah dibandingkan perusahaan laki-laki.

Pada umumnya rumah tangga di Indonesia dikepalai oleh seorang laki-laki, akan tetapi, tidak jarang pula ditemukan perempuan menjadi penanggung jawab di dalam rumah tangga. Data dari BPS (2019) menyebutkan bahwa 15,17\% rumah tangga di Indonesia dikepalai oleh perempuan, dan 84,83\% sisanya merupakan kepala rumah tangga laki-laki. Di dalam studi Klasen et al. (2015) di Thailand menilai bahwa rumah tangga yang dikepalai oleh perempuan lebih kaya dibandingkan rumah tangga laki-laki, namun di Vietnam rumah tangga tersebut rentan terhadap kemiskinan. Rumah tangga yang dikepalai oleh perempuan berbeda secara substansial dalam hal kemiskinan, namun tetap rentan terhadap guncangan. Perempuan yang berstatus janda memiliki probabilitas yang besar untuk menjadi miskin. Drèze \& Srinivasan (1997) menemukan hubungan negatif dan signifikan antara perempuan janda dengan pengeluaran per kapita.

Studi empiris yang dilakukan oleh Chen \& Hamori (2013) menemukan bahwa pendapatan per jam pria di Cina lebih tinggi daripada wanita baik dalam pekerjaan formal maupun informal. Sohn (2015) menyebutkan perempuan mendapat upah sekitar 30\% lebih rendah dibandingkan laki-laki. Bahkan di sektor 
informal banyak ditemukan perempuan bekerja di sektor informal yaitu pekerja keluarga/tidak dibayar. Penelitian terdahulu menemukan pekerja formal memiliki upah atau pendapatan yang lebih tinggi dari pekerja dalam sektor informal (Bargain \& Kwenda, 2011; Khan, 2014; Tansel \& Kan, 2012). Secara umum, perempuan memiliki probabilitas yang lebih besar untuk masuk dalam sektor informal karena pertimbangan untuk merawat dan menjaga anak serta tingkat pendidikan perempuan yang lebih rendah dibandingkan laki-laki (Gallaway \& Bernasek, 2002; International Labor Organization [ILO], 2014).

Kondisi tenaga kerja perempuan akan semakin terpuruk ketika terjadi diskriminasi gender dalam akses di pasar keuangan, rendahnya pendidikan dan adanya guncangan. Salah satu faktor utama yang dapat menentukan partisipasi dalam pekerjaan adalah pendidikan (Wamuthenya, 2010). Pendidikan yang rendah dan tidak memadai akan membatasi produktivitas dan keterampilan seseorang. Bahkan tingkat pendidikan yang tinggi mampu meningkatkan pengeluaran per kapita rumah tangga (Majeed \& Malik, 2015). Perempuan yang memiliki pendidikan lebih baik akan menggunakan proporsi yang lebih besar dari pendapatannya untuk perumahan, pendidikan dan pakaian (Davies, 2011).

Tenaga kerja informal secara sistematis diberikan upah yang lebih rendah dibandingkan dengan sektor formal (Bargain \& Kwenda, 2011). Lebih dari 40\% kesenjangan pendapatan masih disebabkan oleh diskriminasi pasar tenaga kerja di sektor informal (Xue et al., 2014). Temuan Mat et al. (2012) bahkan menyebutkan bahwa pendapatan dari sektor non-pertanian dapat mengurangi tingkat kedalaman dan keparahan kemiskinan. Hal ini dikarenakan pekerjaan di sektor non-pertanian secara signifikan mampu meningkatkan konsumsi makanan di dalam rumah tangga. Bahkan hasil tersebut diharapkan mampu mengurangi kerentanan rumah tangga terhadap pangan (Zereyesus et al., 2017).

Dengan demikian, tujuan dari penelitian ini adalah untuk menganalisis pengaruh dari pekerjaan di sektor informal terhadap kesejahteraan rumah tangga yang dikepalai oleh seorang perempuan. Kesejahteraan akan diproksikan melalui pengeluaran per kapita rumah tangga dan penelitian ini juga akan menggunakan beberapa variabel kontrol sosial-ekonomi seperti karakteristik individu maupun rumah tangga. Setelah bagian ini akan dijelaskan metodologi penelitian. Selanjutnya pada bagian hasil dan pembahasan akan dijelaskan temuan dari estimasi yang telah dilakukan. Bagian penutup dari penelitian ini akan menjabarkan kesimpulan, implikasi, keterbatasan dan saran untuk penelitian berikutnya.

\section{Metodologi}

Penelitian ini menggunakan data sekunder yang bersumber dari Indonesia Family Life Survey (IFLS) gelombang ke-5 tahun 2014 sebagai data mikro yang tersedia paling baru. Tujuan penelitian ini adalah menganalisis pengaruh sektor informal terhadap kesejahteraan rumah tangga yang dipimpin oleh seorang perempuan. Variabel dependen yang digunakan adalah kesejahteraan yang diproksikan melalui pengeluaran per kapita rumah tangga dengan variabel independennya adalah 
sektor informal, status pernikahan, usia, pendidikan, kepemilikan aset, akses listrik, jumlah anggota rumah tangga, dan daerah tempat tinggal. BPS (2018) mendefinisikan pekerjaan dengan kategori berusaha sendiri dengan dibantu oleh karyawan tetap, pegawai swasta dan pegawai pemerintah sebagai kategori pekerjaan sektor formal. Sedangkan pekerjaan yang masuk ke dalam kategori sektor informal adalah jenis pekerjaan yang mencakup berusaha sendiri (tanpa bantuan karyawan), berusaha sendiri dengan dibantu oleh karyawan tidak tetap, pekerja keluarga tidak dibayar, pekerja bebas di pertanian dan non pertanian. Unit analisis penelitian ini merupakan level rumah tangga dan pemilihan sampel dibatasi hanya pada rumah tangga yang dikepalai oleh perempuan. Total sampel di dalam penelitian ini yaitu 1.433 rumah tangga. Penelitian ini akan menganalisis bagaimana pengaruh dari pekerjaan sektor informal terhadap kesejahteraan rumah tangga yang dikepalai oleh perempuan dan hipotesis untuk masalah ini adalah pekerjaan di sektor informal akan berpengaruh terhadap rendahnya pengeluaran per kapita rumah tangga perempuan. Dengan demikian, untuk merepresentasikan permasalahan tersebut, model yang akan digunakan dalam penelitian ini dikembangkan dari model Zereyesus et al. (2017) yang disajikan sebagai berikut:

$$
\begin{aligned}
\text { Inpce }_{i}= & \beta_{0}+\beta_{1} \text { dinformal }_{i}+\beta_{2} \text { status }_{i}+\beta_{3} \text { usia }_{i}+\beta_{4} \text { usia }_{i}^{2}+\beta_{5} \text { pendidikan }_{i} \\
& +\beta_{6} \text { dpertanian }_{i}+\beta_{7} \text { dtabungan }_{i}+\beta_{8} \text { dlistrik }_{i}+\beta_{9} \text { hhsize }_{i}+\beta_{10} \text { dkota }_{i} \\
& +\beta_{11} \text { djawa }_{i}+\varepsilon_{i}
\end{aligned}
$$

Model (1) di atas memiliki variabel dependen $\operatorname{lnpce}_{i}$ yang merupakan $\ln$ dari pengeluaran per kapita rumah tangga $i$. Variabel independen $\operatorname{din}_{\text {formal }_{i} \text { meru- }}$ pakan dummy 1 jika kepala rumah tangga perempuan bekerja di sektor informal dan 0 jika bekerja di sektor formal. Beberapa variabel seperti karakteristik kepala rumah tangga perempuan yaitu status pernikahan (status $\left.s_{i}\right)$, usia $\left(\right.$ usia $\left._{i}\right)$, usia kuadrat $\left(u_{s i a_{i}^{2}}\right)$, lama pendidikan ( pendidikan $\left._{i}\right)$ dan karakteristik rumah tangga yaitu kepemilikan aset lahan pertanian (dpertanian $\left.n_{i}\right)$, tabungan (dtabungan $\left.n_{i}\right)$, akses listrik $\left(\right.$ dlistrik $\left._{i}\right)$, jumlah anggota rumah tangga $\left(h h s i z e_{i}\right)$, area perkotaan $\left(\operatorname{dkota}_{i}\right)$ dan juga Pulau Jawa $\left(\right.$ djawa $\left._{i}\right)$ digunakan sebagai kontrol di dalam penelitian ini.

Di dalam studi Zereyesus et al. (2017) menyebutkan adanya potensi masalah endogenitas terkait dengan partisipasi bekerja di sektor non-pertanian. Isu endogenitas muncul karena keputusan seseorang untuk bekerja dalam sektor formal atau informal dapat dipengaruhi oleh faktor lain di luar model. Hal ini

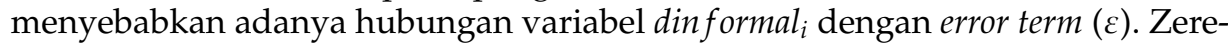
yesus et al. (2017) mengatasi masalah tersebut dengan pendekatan instrumental variable dengan beberapa variabel instrumennya adalah aset rumah tangga, yaitu kepemilikan sepeda motor dan kepemilikan telepon genggam, pendidikan kepala rumah tangga dan pendidikan pasangan kepala rumah tangga. Beberapa penelitian sebelumnya menggunakan variabel ini sebagai variabel instrumen dalam keputusan untuk bekerja di sektor pertanian atau di luar sektor pertanian (Babatunde \& Qaim, 2010; Biyase \& Zwane, 2018). 
Adanya telepon genggam dalam rumah tangga dapat menyebarkan dan mendapatkan informasi tentang pekerjaan dengan biaya yang lebih murah, tanpa harus pergi ke perusahaan untuk mencari pekerjaan (Beuermann et al., 2012). Penelitian ini akan sedikit berbeda dalam menggunakan variabel instrumen, di mana untuk mengatasi endogenitas akan menggunakan variabel kepemilikan kendaraan dan variabel akses internet sebagai variabel instrumen. Hal ini dikarenakan akses internet lebih memudahkan seseorang dalam mencari informasi. Dengan demikian didapat model untuk permasalahan tersebut yaitu:

$$
\operatorname{dinformal}_{i}=\gamma_{0}+\gamma_{1} \text { dkendaraan }_{i}+\gamma_{2} \text { dinternet }_{i}+\varepsilon_{i},
$$

Dengan mengunakan metode Two Stage Least Square (2SLS), di mana estimasi tahap pertama akan menganalisis variabel instrumen terhadap variabel endogen dan di tahap kedua menganalisis permasalahan utama, maka untuk mendapatkan modelnya, persamaan (2) akan dimasukkan ke dalam persamaan (1) sehingga diperoleh model untuk permasalahan utama yaitu sebagai berikut:

$$
\begin{aligned}
\text { Inpce }_{i}= & \beta_{0}+\beta_{1} \text { dinformal }_{i}+\beta_{2 \text { status }_{i}}+\beta_{3} \text { usia }_{i}+\beta_{4} \text { usia }_{i}^{2}+\beta_{5} \text { pendidikan }_{i} \\
& +\beta_{6} \text { dpertanian }_{i}+\beta_{7} \text { dtabungan }_{i}+\beta_{8} \text { dlistrik }_{i}+\beta_{9} \text { hhsize }_{i}+\beta_{10} \text { dkota }_{i} \\
& +\beta_{11} \text { djawa }_{i}+\varepsilon_{i}
\end{aligned}
$$

\section{Hasil dan Pembahasan}

Bagian ini akan menjabarkan hasil analisis dengan menggunakan metode analisis Two Stage Least Square (2SLS) dengan pendekatan instrumental variable. Pada Tabel 1 menampilkan rangkuman statistik deskriptif karakteristik sampel yang digunakan dalam penelitian ini. Rata-rata pengeluaran per kapita di Indonesia 1.435.826 rupiah atau dalam $\ln$ yaitu 13,86. Kepala rumah tangga perempuan di dalam penelitian ini memiliki usia rata-rata berkisar 47 tahun dan rata-rata lama pendidikan yang diselesaikan yaitu 7 tahun atau tidak sampai selesai SMP. Rumah tangga yang diamati di dalam penelitian ini rata-rata memiliki jumlah anggota rumah tangga sebanyak 3 orang.

Selanjutnya, Gambar 1 menunjukkan klasifikasi jenis pekerjaan kepala rumah tangga perempuan di Indonesia. Berdasarkan gambar tersebut terlihat bahwa lebih dari 50\% kepala rumah tangga perempuan bekerja di sektor informal. Terdapat 944 kepala rumah tangga perempuan atau sekitar $65,9 \%$ yang bekerja di sektor informal dan 489 (34,1\%) perempuan bekerja di sektor formal.

Berdasarkan klasifikasi jenis pekerjaan, Tabel 2 menjelaskan bahwa terdapat 440 kepala rumah tangga perempuan atau sekitar 30,7\% bekerja dengan berusaha sendiri. Selain itu, perempuan yang berusaha sendiri dengan bantuan keluarga tidak dibayar sebanyak 287 orang (20,03\%), berusaha sendiri dengan menggunakan karyawan tetap sebanyak 29 orang $(2,02 \%)$, bekerja sebagai pegawai pemerintahan sebanyak 62 orang $(4,33 \%)$, bekerja sebagai pegawai swasta 398 orang $(27,77 \%)$, sebagai pekerja keluarga tidak dibayar 42 orang $(2,93 \%)$, 
Tabel 1: Statistik Deskriptif

\begin{tabular}{lccc}
\hline \hline Variabel & Obs. & Rata-rata & Std. Deviasi \\
\hline Pengeluaran per kapita (lnpce) & 1.433 & 13,86 & 0,76 \\
Sektor informal (dinformal) & 1.433 & 0,66 & 0,47 \\
Status pernikahan (status) & 1.433 & 1,86 & 0,62 \\
Usia kepala rumah tangga (usia) & 1.433 & 47,18 & 15,44 \\
Usia kuadrat (usia ${ }^{2}$ ) & 1.433 & 2464,77 & 1496,35 \\
Lama pendidikan (pendidikan) & 1.433 & 7,02 & 4,99 \\
Kepemilikan lahan pertanian (dpertanian) & 1.433 & 0,25 & 0,43 \\
Kepemilikan tabungan (dtabungan) & 1.433 & 0,3 & 0,46 \\
Akses listrik (dlistrik) & 1.433 & 0,99 & 0,09 \\
Jumlah anggota rumah tangga (hhsize) & 1.433 & 2,66 & 1,63 \\
Area perkotaan (dkota) & 1.433 & 0,6 & 0,5 \\
Pulau Jawa (djawa) & 1.433 & 0,6 & 0,5 \\
Kepemilikan kendaraan (dkendaraan) & 1.433 & 0,52 & 0,5 \\
Akses internet (dinternet) & 1.433 & 0,5 & 0,5 \\
\hline
\end{tabular}

Sumber: IFLS (diolah)

sebagai pekerja bebas di pertanian sebanyak 89 orang $(6,21 \%)$ dan perempuan sebagai pekerja bebas di non-pertanian sebanyak 86 orang $(6 \%)$.

Kategori pekerjaan yang paling banyak dilakukan oleh kepala rumah tangga perempuan yaitu berusaha sendiri tanpa bantuan karyawan dan dengan bantuan keluarga tidak dibayar di mana persentase dua kategori tersebut lebih dari 50\%.

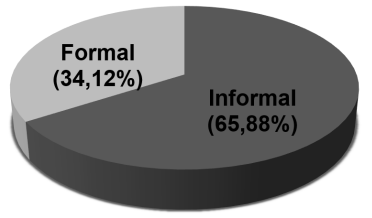

\section{Gambar 1: Klasifikasi Pekerjaan Kepala Rumah Tangga Perempuan Berdasarkan Sektor Formal Informal}

Pada kategori formal, kepala rumah tangga perempuan lebih banyak memilih pekerjaan sebagai pegawai swasta dibandingkan pegawai pemerintahan. Hal ini ditunjukkan dengan adanya 398 (27,77\%) perempuan yang bekerja sebagai pegawai swasta, sedangkan perempuan yang bekerja sebagai pegawai pemerintahan lebih rendah yaitu sebanyak 62 orang atau sekitar 4,3\%. Bahkan untuk kategori formal, hanya $2 \%$ kepala rumah tangga perempuan yang memilih bekerja dengan berusaha sendiri dengan menggunakan karyawan tetap.

Selanjutnya, Tabel 3 menunjukkan kategori pekerjaan berdasarkan status pernikahan kepala rumah tangga perempuan. Di dalam penelitian ini, proporsi kepala rumah tangga perempuan yang berstatus sebagai janda lebih besar dibandingkan perempuan yang belum menikah maupun yang berstatus menikah. 
Tabel 2: Kategori Pekerjaan Kepala Rumah Tangga Perempuan

\begin{tabular}{lcc}
\hline \hline Kategori Pekerjaan & Jumlah & Persentase \\
\hline Sektor Informal & 440 & $30,7 \%$ \\
Berusaha sendiri & 287 & $20,03 \%$ \\
Berusaha sendiri dengan bantuan keluarga tidak dibayar & 42 & $2,93 \%$ \\
Pekerja keluarga tidak dibayar & 89 & $6,21 \%$ \\
Pekerja bebas di pertanian & 86 & $6 \%$ \\
Pekerja bebas non-pertanian & 62 & $4,33 \%$ \\
\hline Sektor Formal & 398 & $27,77 \%$ \\
Pegawai pemerintahan & 29 & $2,02 \%$ \\
Pegawai swasta & & \\
Berusaha sendiri dengan karyawan tetap &
\end{tabular}

Sumber: IFLS (diolah)

Selain itu, perempuan yang berstatus janda lebih banyak ditemukan pada rumah tangga sektor informal dibandingkan sektor formal. Kepala rumah tangga perempuan yang memiliki usaha sendiri dan berstatus sebagai janda berjumlah sebanyak 305 orang sedangkan yang berstatus menikah berjumlah sebanyak 112 orang. Perempuan yang memiliki usaha sendiri dengan bantuan keluarga tidak bayar dan berstatus sebagai janda sebanyak 208 orang sedangkan yang menikah sebanyak 71 orang. Di dalam sektor formal, kepala rumah tangga perempuan yang bekerja sebagai pegawai swasta dan berstatus sebagai janda sebanyak 157 orang sedangkan yang berstatus menikah sebanyak 120 orang dan yang belum menikah sebanyak 121 orang.

Hasil analisis dari penelitian ini dijelaskan pada Tabel 4. Berdasarkan tabel tersebut, terdapat tiga hasil estimasi. Estimasi Model 1 merupakan estimasi tanpa menggunakan variabel kontrol. Hasil temuan model ini menyatakan bahwa partisipasi kepala rumah tangga perempuan yang bekerja di sektor informal secara signifikan $(p<0,01)$ memiliki hubungan negatif dengan pengeluaran per kapita. Artinya dibandingkan sektor formal, bekerja di sektor informal mampu menurunkan kesejahteraan rumah tangga melalui pengeluaran per kapita yang lebih rendah. Temuan tersebut dapat dikarenakan kesenjangan pendapatan atau upah yang diterima antara pekerja formal dan pekerja informal. Beberapa penelitian menemukan bahwa upah pekerja formal lebih besar dibandingkan pekerja informal (Bargain \& Kwenda, 2011; Tansel \& Kan, 2012).

Selanjutnya, hasil estimasi pada kolom Model 2 dengan melibatkan karakteristik dari kepala rumah tangga perempuan menemukan bahwa partisipasi perempuan pada sektor informal tidak memberikan pengaruh yang signifikan pada kesejahteraan rumah tangga di Indonesia. Temuan ini memberikan hasil bahwa variabel lain justru lebih memberikan pengaruh pada kesejahteraan rumah tangga. Status pernikahan dan umur dari kepala rumah tangga perempuan memiliki hubungan negatif dan signifikan terhadap pengeluaran per kapita rumah tangga perempuan. Perempuan yang menikah atau yang bercerai memiliki kesejahteraan rumah tangga yang lebih rendah dibandingkan perempuan yang belum menikah. Hal ini dapat disebebkan oleh perempuan yang belum menikah 
Tabel 3: Kategori Pekerjaan Kepala Rumah Tangga Perempuan Berdasarkan Status Pernikahan

\begin{tabular}{lccc}
\hline \hline Kategori Pekerjaan & Menikah & $\begin{array}{c}\text { Pisah/ } \\
\text { Cerai }\end{array}$ & $\begin{array}{c}\text { Belum } \\
\text { Menikah }\end{array}$ \\
\hline Sektor Informal & 112 & 305 & 23 \\
Berusaha sendiri & 71 & 208 & 8 \\
Berusaha sendiri dengan bantuan keluarga tidak dibayar & 10 & 25 & 7 \\
Pekerja keluarga tidak dibayar & 23 & 64 & 2 \\
Pekerja bebas di pertanian & 22 & 53 & 11 \\
Pekerja bebas non-pertanian & & & \\
\hline Sektor Formal & 19 & 33 & 10 \\
Pegawai pemerintahan & 120 & 157 & 121 \\
Pegawai swasta & 10 & 17 & 2 \\
Berusaha sendiri dengan karyawan tetap & & &
\end{tabular}

belum memiliki tanggungan anak di dalam rumah tangga.

Satu tahun pertambahan usia seorang perempuan yang lebih dewasa mampu menurunkan pengeluaran per kapita rumah tangga, akan tetapi seiring bertambahnya waktu akan ada kondisi di mana adanya titik balik dari pertambahan usia yang semakin meningkat maka pengeluaran per kapita rumah tangga juga akan meningkat. Selain itu, kepala rumah tangga perempuan yang memiliki pendidikan yang lebih tinggi secara signifikan $(\mathrm{p}<0,01)$ mampu meningkatkan pengeluaran per kapita. Hal ini sejalan dengan Majeed \& Malik (2015) yang menemukan bahwa pendidikan secara signifikan dapat meningkatkan pengeluaran per kapita bahkan Davies (2011) menyatakan bahwa pilihan konsumsi dalam rumah tangga tidak hanya dipengaruhi oleh pendapatan tetapi juga dipengaruhi oleh pendidikan kepala rumah tangganya.

Di dalam Model 3, variabel kontrol yang dilibatkan di dalam model ini tidak hanya karakteristik individu dari perempuan yang menjadi kepala rumah tangga namun juga menggunakan variabel kontrol karakteristik rumah tangga. Hasil temuan di dalam model ini menunjukkan bahwa partisipasi perempuan di dalam sektor informal secara signifikan berhubungan negatif dengan pengeluaran per kapita rumah tangga perempuan.

Terlepas dari sektor pekerjaan kepala rumah tangga perempuan, Drèze \& Srinivasan (1997) menemukan bahwa rumah tangga yang dikepalai perempuan cenderung memiliki pengeluaran per kapita yang lebih rendah dibandingkan kepala rumah tangga laki-laki. Analisis dalam penelitian ini tidak menemukan adanya pengaruh yang signifikan antara status pernikahan perempuan terhadap pengeluaran per kapita. Hal ini tidak sejalan dengan Appleton (1996) yang menemukan bahwa kepala rumah tangga perempuan yang berstatus janda akan memiliki kecenderungan yang lebih besar untuk menjadi miskin.

Variabel lain yang ditemukan berhubungan negatif dan signifikan terhadap pengeluaran per kapita adalah usia kuadrat, jumlah anggota rumah tangga dan wilayah Pulau Jawa. Usia kuadrat menandakan bahwa seiring penambahan usia 
Tabel 4: Hasil Analisis Menggunakan Instrumental Variable

\begin{tabular}{|c|c|c|c|}
\hline Variabel & Model 1 & Model 2 & Model 3 \\
\hline Sektor informal & $\begin{array}{c}-1,108^{* * *} \\
(0,184)\end{array}$ & $\begin{array}{c}0,568 \\
(0,606)\end{array}$ & $\begin{array}{c}-1,995^{* * *} \\
(0,657)\end{array}$ \\
\hline Status pernikahan & & & \\
\hline Menikah & & $\begin{array}{c}-0,525^{* * *} \\
(0,115)\end{array}$ & $\begin{array}{l}0,0188 \\
(0,131)\end{array}$ \\
\hline Pisah/Cerai & & $\begin{array}{c}-0,434^{* * *} \\
(0,106)\end{array}$ & $\begin{array}{r}-0,0480 \\
(0,130)\end{array}$ \\
\hline Belum menikah & & \multicolumn{2}{|c|}{ Base } \\
\hline Umur & & $\begin{array}{l}-0,0239^{*} \\
(0,0137)\end{array}$ & $\begin{array}{l}0,0385^{* *} \\
(0,0156)\end{array}$ \\
\hline $\mathrm{Umur}^{2}$ & & $\begin{array}{l}0,000236^{* *} \\
(0,000106)\end{array}$ & $\begin{array}{l}-0,000239^{*} \\
(0,000135)\end{array}$ \\
\hline Lama pendidikan & & $\begin{array}{c}0,0785^{* * *} \\
(0,0159)\end{array}$ & $\begin{array}{l}0,00870 \\
(0,0168)\end{array}$ \\
\hline Kepemilikan lahan pertanian & & & $\begin{array}{c}0,182^{*} \\
(0,0946)\end{array}$ \\
\hline Kepemilikan tabungan & & & $\begin{array}{l}0,241^{* * *} \\
(0,0628)\end{array}$ \\
\hline Akses listrik & & & $\begin{array}{c}0,202 \\
(0,224)\end{array}$ \\
\hline Jml. Anggota rumah tangga & & & $\begin{array}{c}-0,154^{* * *} \\
(0,0210)\end{array}$ \\
\hline Area perkotaan & & & $\begin{array}{c}0,0204 \\
(0,0778)\end{array}$ \\
\hline Pulau Jawa & & & $\begin{array}{c}-0,192^{* * *} \\
(0,0643)\end{array}$ \\
\hline _cons & $\begin{array}{c}14,59 * * * \\
(0,121)\end{array}$ & $\begin{array}{c}13,89^{* * *} \\
(0,223)\end{array}$ & $\begin{array}{c}14,11^{* * *} \\
(0,441)\end{array}$ \\
\hline $\mathrm{N}$ & 1.433 & 1.433 & 1.433 \\
\hline
\end{tabular}

yang lebih tinggi maka kesejahteraan semakin rendah. Sama halnya dengan jumlah anggota rumah tangga, yang makin banyak maka pengeluaran per kapita atau kesejahteraannya menurun.

Dapat dilihat dari hasil ini bahwa rumah tangga yang dikepalai oleh perempuan yang tinggal di Pulau Jawa memiliki kecenderungan pengeluaran per kapita yang lebih rendah dibandingkan rumah tangga yang berada di luar Pulau Jawa. Sedangkan variabel usia, kepemilikan lahan dan kepemilikan tabungan secara signifikan mampu meningkatkan kesejahteraan yang lebih besar.

Berdasarkan hasil tersebut, rumah tangga sektor informal yang dikepalai oleh perempuan memiliki pengeluaran per kapita 6 kali lebih rendah dibandingkan rumah tangga sektor formal. Ini artinya bahwa kesejahteraan rumah tangga perempuan sektor informal jauh lebih rendah dibandingkan rumah tangga perempuan sektor formal. Dengan demikian, dapat dikatakan bahwa kesejahteraan rumah tangga perempuan sektor informal akan meningkat ketika kepala rumah 
tangga perempuan tersebut memiliki umur yang semakin dewasa, memiliki aset berupa lahan pertanian, memiliki tabungan. Sedangkan apabila rumah tangga tersebut memiliki anggota rumah tangga dalam jumlah yang banyak dan tinggal di pulau Jawa maka dapat menurunkan tingkat kesejahteraannya. Hasil penelitian ini pada dasarnya sejalan dengan Sohn (2015) yang menemukan bahwa perempuan yang bekerja di sektor informal memiliki kesejahteraan yang lebih rendah. Bahkan Zereyesus et al. (2017) lebih khusus menekankan bahwa partisipasi dalam pekerjaan non-pertanian secara signifikan mampu meningkatkan konsumsi rumah tangga.

\section{Kesimpulan}

Disparitas pendapatan ditemukan di antara pekerja sektor formal dan sektor informal. Di dalam penelitian ini digunakan informasi mengenai karakteristik individu dari perempuan yang menjadi kepala rumah tangga dan juga karakteristik rumah tangga tersebut untuk melihat perbedaan kesejahteraan antara rumah tangga perempuan sektor formal dan informal melalui sisi pengeluaran per kapita. Rumah tangga perempuan sektor informal memiliki kesejahteraan yang lebih rendah dibandingkan rumah tangga sektor formal. Selain itu, kesejahteraan rumah tangga yang dikepalai oleh perempuan akan meningkat ketika memiliki aset seperti lahan pertanian dan juga tabungan.

Hal menarik yang ditemukan dalam penelitian ini yaitu terdapat kesenjangan yang terjadi ketika rumah tangga tinggal di pulau Jawa akan memiliki kesejahteraan yang lebih rendah dibandingkan rumah tangga yang berada di luar Jawa. Hal ini dimungkinkan terjadi karena perekonomian masih terkonsentrasi di Pulau Jawa namun penduduknya semakin padat sehingga bagi rumah tangga perempuan terutama yang bekerja di sektor informal akan rentan dan berdampak pada kehidupannya ketika terjadi guncangan ekonomi. Selain itu, status pernikahan, pendidikan, akses listrik dan juga area tempat tinggal tidak secara signifikan memengaruhi kesejahteraan rumah tangga perempuan.

Berdasarkan hasil penelitian ini, implikasi kebijakan yang dapat diperhatikan adalah perluasan akses pendidikan bagi perempuan untuk mengurangi kesenjangan pendidikan. Hal ini dikarenakan fakta bahwa pendidikan merupakan salah satu modal bagi perempuan untuk dapat keluar dari diskriminasi dan dapat berkesempatan untuk beralih dari sektor informal ke sektor formal dengan pendapatan yang lebih baik. Selain itu, perlu adanya bantuan dan perlindungan sosial terhadap rumah tangga yang dikepalai perempuan khususnya yang pekerjaan utamanya di sektor informal, memiliki tanggungan yang besar dan tidak memiliki pasangan atau suami dalam menghadapi guncangan. Dengan memberikan dukungan yang salah satunya berupa kemudahan dan kepercayaan akses kredit ke lembaga formal maka dapat membantu rumah tangga tersebut dalam usaha, produktivitas, dan kelangsungan hidupnya.

Kebijakan lainnya terletak pada keleluasaan bagi para perempuan yang sudah menikah untuk mendapatkan kesempatan bekerja di sektor formal. Sebab masih 
cukup banyak perusahaan yang menetapkan kualifikasi pekerjaan hanya terbuka bagi perempuan yang belum menikah. Dengan demikian, dari keseluruhan penelitian ini setelah mendapatkan hasil estimasi, kesimpulan dan implikasi kebijakan tentunya peneliti menyadari adanya keterbatasan dalam penelitian ini. Keterbatasan data di mana sampel yang diobservasi di dalam penelitian ini dimungkinkan tidak dapat mewakili kondisi yang sebenarnya terjadi di Indonesia. Oleh karena itu, perlu adanya penelitian selanjutnya yang dapat melakukan pengambilan sampel lebih baik dalam mewakili kondisi yang terjadi di Indonesia.

\section{Daftar Pustaka}

[1] Appleton, S. (1996). Women-headed households and household welfare: An empirical deconstruction for Uganda. World Development, 24(12), 1811-1827. doi: https://doi.org/10.1016/S0305-750X(96)00089-7.

[2] Babatunde, R. O., \& Qaim, M. (2010). Impact of off-farm income on food security and nutrition in Nigeria. Food Policy, 35(4), 303-311. doi: https://doi.org/10.1016/j.foodpol.2010.01.006.

[3] Bargain, O., \& Kwenda, P. (2011). Earnings structures, informal employment, and selfemployment: New evidence From Brazil, Mexico, and South Africa. Review of Income and Wealth, 57, S100-S122. doi: https://doi.org/10.1111/j.1475-4991.2011.00454.x.

[4] Beuermann, D. W., McKelvey, C., \& Vakis, R. (2012). Mobile phones and economic development in rural Peru. The Journal of Development Studies, 48(11), 1617-1628. doi: https://doi.org/10.1080/00220388.2012.709615.

[5] Biyase, M., \& Zwane, T. (2018). An empirical analysis of the determinants of poverty and household welfare in South Africa. The Journal of Developing Areas, 52(1), 115-130. doi: https://doi.org/10.1353/jda.2018.0008.

[6] BPS. (2018). Laporan bulanan data sosial ekonomi Desember 2018. Badan Pusat Statistik.

[7] BPS. (2019). Perempuan dan laki-laki di Indonesia 2018. Badan Pusat Statistik.

[8] Canagarajah, S., Newman, C., \& Bhattamishra, R. (2001). Non-farm income, gender, and inequality: evidence from rural Ghana and Uganda. Food Policy, 26(4), 405-420. doi: https:/ / doi.org/10.1016/S0306-9192(01)00011-2.

[9] Chen, G., \& Hamori, S. (2013). Formal and informal employment and income differentials in urban China. Journal of International Development, 25(7), 987-1004. doi: https://doi.org/10.1002/jid.1825.

[10] Davies, S. (2011). Income, gender, and consumption: A study of Malawian households. The Journal of Developing Areas, 44(2), 1-25.

[11] Drèze, J., \& Srinivasan, P. V. (1997). Widowhood and poverty in rural India: Some inferences from household survey data. Journal of Development Economics, 54(2), 217234. doi: https:/ /doi.org/10.1016/S0304-3878(97)00041-2.

[12] Gallaway, J. H., \& Bernasek, A. (2002). Gender and informal sector employment in Indonesia. Journal of Economic Issues, 36(2), 313-321. doi: https:/ / doi.org/10.1080/00213624.2002.11506473.

[13] ILO. (2014). Indonesia: Pekerjaan rumahan di Jawa Timur - Temuan dari penelitian kualitatif. International Labor Organization. https://www.ilo.org/wcmsp5/groups/public/ ---asia/---ro-bangkok/---ilo-jakarta/documents/publication/wcms_370359.pdf.

[14] Khan, H. (2014). An empirical investigation of consumption function under relative 
income hypothesis: Evidence from farm households in northern Pakistan. International Journal of Economic Sciences, 3(2), 43-52.

[15] Klasen, S., Lechtenfeld, T., \& Povel, F. (2015). A feminization of vulnerability? Female headship, poverty, and vulnerability in Thailand and Vietnam. World Development, 71, 36-53. doi: https://doi.org/10.1016/j.worlddev.2013.11.003.

[16] Majeed, M. T., \& Malik, M. N. (2015). Determinants of household poverty: Empirical evidence from Pakistan. The Pakistan Development Review, 54(4), 701-717.

[17] Mat, S. H. C., Jalil, A. Z. A., \& Harun, M. (2012). Does non-farm income improve the poverty and income inequality among agricultural household in rural Kedah?. Procedia Economics and Finance, 1, 269-275. doi: https:/ /doi.org/10.1016/S22125671(12)00031-7.

[18] Nagler, P., \& Naudé, W. (2017). Non-farm entrepreneurship in rural subSaharan Africa: New empirical evidence. Food Policy, 67, 175-191. doi: https://doi.org/10.1016/j.foodpol.2016.09.019.

[19] Narayan, K. (2011). Urban women participation and livelihoods in the informal sector in Fiji: a case study of Suva-Lami Area (Master Thesis, The University of the South Pacific, Suva). http://digilib.library.usp.ac.fj/gsdl/collect/usplibr1/index/assoc/ HASH1ce6.dir/doc.pdf.

[20] Rijkers, B., \& Costa, R. (2012). Gender and rural non-farm entrepreneurship. World Development, 40(12), 2411-2426. doi: https://doi.org/10.1016/j.worlddev.2012.05.017.

[21] SOFA Team \& Doss, C. (2011). The role of women in agriculture. ESA Working Paper 11-02. Food and Agriculture Organization of the United Nations (FAO). http: //www.fao.org/sustainable-food-value-chains/library/details/en/c/265584/.

[22] Sohn, K. (2015). Gender discrimination in earnings in Indonesia: A fuller picture. Bulletin of Indonesian Economic Studies, 51(1), 95-121. doi: https://doi.org/10.1080/00074918.2015.1016569.

[23] Tansel, A., \& Kan, E. O. (2012). The formal/informal employment earnings gap: Evidence from Turkey. IZA Discussion Paper 6556. IZA - Institute of Labor Economics. https://www.iza.org/publications/dp/6556/ the-formalinformal-employment-earnings-gap-evidence-from-turkey.

[24] Wamuthenya, W. R. (2010). Determinants of employment in the formal and informal sectors of the urban areas of Kenya. AERC Research Paper 194. African Economic Research Consortium Research. https:/ /www.africaportal.org/publications/ determinants-of-employment-in-the-formal-and-informal-sectors-of-the-urbanareas-of-kenya/.

[25] Xue, J., Gao, W., \& Guo, L. (2014). Informal employment and its effect on the income distribution in urban China. China Economic Review, 31, 84-93. doi: https://doi.org/10.1016/j.chieco.2014.07.012.

[26] Zereyesus, Y. A., Embaye, W. T., Tsiboe, F., \& Amanor-Boadu, V. (2017). Implications of non-farm work to vulnerability to food poverty-recent evidence from Northern Ghana. World Development, 91, 113-124. doi: https://doi.org/10.1016/j.worlddev.2016.10.015. 